\title{
Contributing to the creative economy imaginary: universities and the creative sector Simon Moreton
}

\author{
Pre-published version. Final version, published in Cultural Trends: \\ https: / / doi.org/10.1080/09548963.2018.1534575
}

\begin{abstract}
This paper explores the relationship between the creative economy and universities. As funders, educators and research bodies, universities have a complicated relationship with the creative economy. They propagate its practice, 'buying-in' to the rhetoric and models of creative value, particularly in teaching, research and knowledge exchange. Third mission activities also play a role, seeking to affect change in the world 'outside' academia through collaboration, partnerships, commercialisation and social action. For arts and humanities disciplines, these practices have focused almost exclusively on the creative sector in recent years. This paper asks how the third mission has been a site where universities have modified their function in relation to the creative economy. It considers the mechanisms by which universities have been complicit in propagating the notion of the creative economy, strengthening particular constructions of the idea at the level of policy and everyday practice. It also briefly asks how a focus on alternative academic practice and institutional forms might offer possibilities for developing a more critical creative economy. The argument made is that the university sector is an important agent in the shaping and performance of the creative economy, and that we should take action if we wish to produce a more diverse, equitable space for learning, researching, and being under the auspices of 'creativity'.
\end{abstract}

\section{Introduction}

'Creativity' has represented one of the defining preoccupations of many economies for over twenty years, visible in a range of connected debates about commercialising cultural practice, industrial classifications, new business forms, education, urban regeneration, and many other areas of everyday life. However, the ubiquity of this 'creative economy' and its attendant discourses has tended to mask its instrumental roots as an economic policy obscuring how a concept as attractive 'creativity' could in fact be merely a tool for neo-liberalisation, individuation, and capitalist exploitation (Peck, 2005).

British universities have become increasingly dependent upon engagements with the creative economy as a means of demonstrating their institutional legitimacy in a time of public funding 
cuts. The demonstration of universities' commercial value has been largely - although not exclusively - articulated through its 'third mission', activities outside of teaching and research that contribute to the economic and social fabric of the world 'outside' the ivory tower, but with a predominant focus on the commercialisation of knowledge outputs for economic gain (Wright and Shore, 2017). The requirement to engage in such activities has been felt particularly keenly by disciplines outside of science, technology, mathematics and engineering (STEM), whose economic impacts are arguably harder to quantify than those whose outputs that have more tangible market value.

My focus in this paper is on how the creative economy, as both policy object and performative discourse, has impacted upon the role that the state, funders, stakeholders, and universities themselves are asking their staff to play in the commercialisation of academic knowledge and practice. Specifically, I'm curious as to what the retooling of these relationships into a conversation about 'commercialisation' tells us about how contemporary universities are becoming implicated in the production of a normative creative economy. I write this paper from the point of view of a researcher who has spent the last seven years actively involved in the research, evaluation, and production of 'knowledge exchange' projects that sit at the interface between universities and the creative economy. I use this term to refer broadly to activities that mobilise creativity in some way in their day to day function, whether or not they appear in the state's classification of a creative industry. My reflections come from both research and daily professional practices. This includes the analysis of over 150 interviews with academics, administrators, and practitioners involved in collaborative R\&D projects, many hours spent on boards at all levels of project management in this field, participant observation at events, alongside bid-writing, project promotion, event planning and policy advocacy. As such the paper, although reflective and theoretical, emerges from a long period of empirical work which has left me questioning precisely what our role as researchers is in this field - critical researchers, or problematic policy advocates? Finally, although my analysis largely addresses academics working in university 'third mission' contexts, I hope the arguments made here will have a wider resonance within the sector by calling us to consider our complicity in the reproduction of 'creative capitalism'.

\section{The emergence of a creative economy}

The UK creative economy narrative begins, in many respects (though not all, as Hewison (2011) has pointed out), with the election of Tony Blair's Labour government in 1997. The administration succeeded nineteen years of Conservative government that had overseen a dismantling of many state institutions as part of a programme of neo-liberalisation. Labour had emerged as a party dedicated to finding a 'third way' between the socialist driven 
traditional Labour politics, and the destructive excesses of right-wing neoliberalism (Hughson and Inglis, 2001). Part of this programme of activity was the emergence of a range of now landmark documents that sought to redefine what constituted 'cultural' and 'creative' activity (DCMS, 2001, 1998). These documents introduced 'creative industries' as a new industrial category. They comprised activities which harnessed 'creativity' in the production of largely cultural goods, including computer games, film and television, advertising, antiques markets and publishing. The rhetoric surrounding these documents - if not their specific definitions encompassed other established activities in the cultural sector, such as museums and art galleries (Garnham, 2005).

The aim was to culturally and politically instantiate 'creativity' as a social and economic force for change. Borrowing from 'old' Labour traditions that access to culture was a core part of social cohesion, the ambition was to revive the place that 'culture' has at the heart of British society (Oakley, 2006). A further step, linking culture to creativity, as both its source and its product, the term was reinvented as an innate and democratic principle to which we could aspire, despite the deep contradictions this implied (Miller, 2009).

'Creativity' whether represented by the creative industries, in the arts, or social policy, became seen as a panacea for the new economic age, that would be politically progressive, holistically tackle social and economic challenges, and above all, be lucrative (Hesmondhalgh et al., 2015b). Academics and theorists began to provide evidence about how 'creativity' could support growth - individual, economic, social, urban, and national. Not only that, but creative consumption offers new, alluring, ways of life for professionals wishing to consume, rather than contribute to the production of, creative practices (Banks, 2009).

Although calculation, measurement and mapping became key discourses in rationalising what was creative, what was not, and where it was happening (Bakhshi et al., 2013; Mommaas, 2004; Prince, 2013), the policies were - and continue to be - assembled on shaky ground (Hewison, 2011). Poorly evidenced, largely misunderstood, and unnuanced in their thinking, the creative industries were quickly identified as problematic for replicating social inequalities, ignoring existing cultural markets, and assuming economic and social value were unproblematically symbiotic (Banks and Hesmondhalgh, 2009; Gill and Pratt, 2008; Hesmondhalgh, 2007; Ross, 2007).

Nevertheless, the expansion of the logics of creative capitalism is demonstrable in the very use of the term 'creative economy'. Although on the one hand it offers a more holistic, allencompassing term that refers to the various ways knowledge or creative capitalisms are being played out, it is on the other hand a specific, technical and political discourse used 
measure 'creative labour' within all areas of the economy (Bakhshi et al., 2013). This colonisation of other areas of work has done little to challenge the notion that creative policies represent a quasi-neoliberalisation of British cultural life (Hesmondhalgh et al., 2015a), opening cultural value, production and consumption up to the logics of the market (Hewison, 2011), and turning creativity into an act of individuation, rather than collectivisation (McGuigan, 2010).

\section{Knowledge economies and Higher Education}

Although New Labour's creative and cultural policy represents a vivid marker of the emergence of creative economy policy in the UK, the logics of creative economics did not begin here (Garnham, 2005). Instead, it came from an international discussion that positioned knowledge-intensive activities, as seek a new form of global commodity. This idea drew its origins from a variety of related ideologies on the changing nature of post-industrial society (Bell, 1973; Hayek, 1945). Knowledge-based economies were understood to be "directly based on the production, distribution and use of knowledge and information" (OECD, 1996, p. 7). With global exchange shifting from goods to services, expertise, and virtual commodities, it spoke to a fundamental shift in not only in what could be produced, sold, moved, made, or mobilised, and how that work would be carried out (David and Foray, 2007; Jessop, 2000).

Globally, the Higher Education sector had been already struggling intellectually and practically with this move towards a knowledge economy. While many in universities have resisted the idea that knowledge should function as, "a contemporary and dominant manifestation of capitalism" (Kenway et al., 2006, p. 4), "rather than as a social good" (Bullen et al., 2004, p. 3), universities have not escaped the fact that their mission, relevance, or survival, has become increasingly predicated on participation in (rather than navigation around) these changes (Marteen et al., 2009). With manufacturing in decline, the United Kingdom had been increasingly compelled during the rise of the creative industries to "use 'knowledge' to sustain its competitive advantage" (Pratt, 2005, p. 33). This has become ever more acute, not least now under the attenuating pressures of post-crash austerity, the looming spectre of Brexit, and the anxieties around automation, exports, productivity and growth evident in current UK industrial policy. The creative industries, which "resonated with the belief that Britain's economic future lay with the move towards an increasingly knowledgebased economy, with its premium on higher learning and education levels, qualifications (that help to ensure labour mobility) and flexible working" (Oakley, 2004, p. 96), has directly implicated universities in the production of creative labour for the knowledge market. 
This took two interrelated forms. Firstly, it has turned university staff into creative labour themselves, either as researchers participating in knowledge exchange, business development or incubation programmes, or as strategists engaging in creating industry-university collaborations. Secondly, this has reconfigured the possibilities for, and expectations of, students, from an expectation to receive entrepreneurial training, to a demand - from the state, and increasingly students themselves - to be 'workforce ready' (Comunian et al., 2011). Teaching has been increasingly instrumentalised to this end (not least in the Teaching Excellence Framework which uses graduate employment as an indicator of teaching quality), and research projects are required to have components that conform to either the logic of commercialisation, whether or not outputs are 'market compatible' (Bullen et al., 2004), or demonstrate their 'impact', as measured for example in the UK by the Research Excellence Framework (Watermeyer and Chubb, 2018).

These changes have been accompanied in the UK by stringent cuts to state funding of universities, a shift to increased tuition fees, and a move to a consumer-led model of education provision. In the case of both TEF and REF, the amount of money available to universities from the state is further constrained by an underlying logic of entrepreneurialism, commercialisation, and personal and professional gain measured in economic productivity, rather than more traditional forms of intrinsic cultural value or 'education for education's sake'. This is visible in work coming from consortia like Universities UK (2010) and University Alliance (Williams et al., 2018) who have sought to reframe the argument away from direct commercial impact by demonstrating the range of value the sector offers; "higher education," argue Universities UK, "is the primary producer of the talent and skills that feed the creative industries and an important source of research that informs new ideas, practices and business models, with applicability within and beyond the creative sectors" (UUK, 2010 p. iii). In this sense, the response has been to walk the line between the intangible benefits of cultural education, and the demand in the job circuit for talent to fill roles in the sector.

Arts and humanities, creative economy, and the third mission

The creative economy, with its collapsing of social, cultural, and economic value, has become the de facto for non-STEM subjects to engage in third mission activities. This is in some ways unsurprising, not least because relationships have long existed between universities and the cultural sector. These range from institutional relationships between cultural organisations, to public and commercial work by historians, archaeologists, translators, linguists, curators, and others. Practice-based academics in many UK universities, especially the former polytechnics or 'post-1992' universities, are also frequently drawn from industries such as TV and film, media production, the gaming sector, fine art, illustration, and other forms of 
commercial creative activity. The challenge posed by the creative economy-third mission debate, however, is in the way that it consistently frames creative activities in economic terms. As I have written elsewhere (Moreton, 2016) the contemporary pattern of engagement has increasingly become about collaborative work with creative firms or institutions largely to achieve outcomes such as jobs creation, new products, services or businesses models. It was this shift that led to Geoffrey Crossick's rebuttal of the 'widget-' or commodity-centric outcomes expected of knowledge exchange, in which he emphasised the value of more ephemeral, process-led practices of cultural production as being a core asset of the sector (Crossick, 2006).

This produces at least two interrelated challenges. The first is how non-STEM subjects are being expected to make accounts of their value that are legible to the economic bottom-line of contemporary economic policy, frequently in ways irrelevant of their social or cultural contribution (Belfiore, 2015). This is in part because many of the methods aimed at supporting, measuring, or delivering knowledge exchange have been developed in science and technology disciplines (Mould et al., 2009). The second challenge, if we consider alternative accounts of creativity as being 'more-than-economic', is how complicit are we in maintaining the status quo of a problematic creative economy, and in so doing are also re-constituting the role of the university in line with that construct. How might we think differently, and less deterministically, about this situation?

\section{(Dis)assembling the creative economy-third mission}

I suggest that to decompose how these processes are at work in the creative economy involves "identifying, accepting and examining multiple, uneven and paradoxical expressions of governmental and political power" (Larner, 2011 p. 332) that underpin our creative economythird mission activities. As Obsorne (2003 p. 508) reminds us, the rise of the creative economy is "a product of human agency and the machinations of experts and - loosely speaking - of workers of the intellect. It is, then, as much a matter of our governmentality as of ideology." This is useful to be reminded of, as it leads us to attend to the multiple ways in which policy is enacted, through discourse, subjects and spaces (Rose-Redwood, 2006, Larner and Le Heron, 2002, Rose, 1999). This is particularly pertinent when investigating how creative work operates in contemporary society, especially when we take into account analyses of the nature of creativity as a means of governing at a distance distinctive forms of work and lifestyles (Bill, 2008; Fougere and Solitander, 2010) or the way knowledge about creative economies is managed through measurement and administrative techniques (Christophers, 2007). 
Prince $(2017,2014,2012)$ has argued that thinking about the creative economy through a lens of 'assemblage' is a fruitful way to conduct an analysis that emphasises relationality, and contingency. Assemblage theory, suggests Prince (2017 p. 336), “approaches socio-spatial forms as heterogeneous assemblages of human and non-human materials arranged through the active but often unpredictable manipulation of those materials and often narrativised as an organic whole". Assemblage theory recognises that such constructs are often incoherent, contradictory, even where a range of methods are adopted which present that assemblage as coherent. This analytical approach can reveal how organisations construct who to govern, how they govern, and what ends they wish to achieve through governing in that way. If the creative economy can be understood as an assemblage, it stands to reason that the third mission can also be understood as such, and that its interaction with the creative economy is in itself also performative, contingent, and relational. I suggest that if we can draw attention to the underlying incoherency of this assemblage, we can find space within it to see how dominant political ideologies about creativity are reproduced, and perhaps even how to subvert them - should that be our wish. In what remains of this paper, I consider a few interrelated ways in which this might be achieved.

\section{Space, time, expertise and calculation}

The first step might be to think about the spaces where we are conducting creative-economy third mission activities. As Rose (1999, pp. 33-40) points out, space does not simply represent a terrain upon which our attempts to deliver or enact policy is performed, but instead is constituted by the processes that underpin that policy; and indeed the process that imagine, divide, regulate and otherwise describe spatial arrangements are also performed in its management (Elden, 2007). The use of spatial metaphors is common across the creative economy, such as clusters, quarters, districts. It is also visible in creative-university collaborations, particularly 'third spaces', quasi-independent initiatives in which partnerships between universities and external bodies such as other universities, local authorities, cultural providers, or businesses are established to variously accelerate or support local businesses, graduates, or alumni, or conduct interdisciplinary work that faces the public in ways conventional research might not (Comunian and Gilmore, 2016). The production and management of these venues spatialises the logics of a third mission, set its possibilities, and regulates its boundaries, bodies, and attenuates participation. This is also true in other areas of university life including the boardrooms, corridors, and administrative and academic networks, where the ideas are made, remade, governed or contested.

Secondly, we should consider how time is understood in the assemblage. Vostal and Robertson (2012) point out that universities have long represented a paradox; on the one hand 
as institutions attempting to secure time for reflection, research and enquiry whilst also acting as agencies for 'progress', a term increasingly synonymous with rapidity, action, and change. In creative work, speed, novelty, flexibility and responsiveness are all hallmarks of productivity (McRobbie, 2002). The third-mission academic, especially those at work in the creative economy, is often required, expected, or hoped - depending on the form of governmentality which a project is subjected - to work at different rates (Shore and McLauchlan, 2012). We are being sped up and 'geared' to match the imagined temporal logics of the creative economy. But are these logics even sound? Gill and Donaghue (2016) refer to the rate at which academia is changing and the real and affective problems it causes for staff, both academic and professional. Precariousness, unbalanced workloads, competing demands on time for administration, bid writing, pastoral care, teaching, research and dissemination are combining to create a challenging environment for people working in universities (Pereira, 2016). Yet Thrift (2000) argues that contemporary capitalist cultures have led to the simultaneous acceleration of the pace of working practices, and the contraction of timescales within which to deliver that work. This will be familiar to many areas of work not least academics, whose professional temporalities have often been slower and more deliberative, with research practices, publishing, and funding designed to function over periods of years, not days, weeks or months. Furthermore, is the pace of work in the creative sector an economic necessity, rather than a choice? Precarity and self-exploitation are sold as defining and desirable characteristics (Ross, 2008) but are in fact deeply problematic.

A third means of assembling the third mission is through the constitution of expertise. Here actors are afforded capacity to, variously, organise, perform, broker, translate, or articulate, the values of the assemblage. Here, the idea of the 'mediator' (Osborne, 2004) is frequently invoked, actors responsible for bridging, and sometimes embodying, the contradictory positions of the assemblage. At the university, these roles, increasingly occupied by research officers and professional services, but also by academics, entail acting as champions, cheerleaders, or intermediaries of one sort or another for the third mission activities. Their role is "to create the spaces and channels that move ideas between the university and the wider economy and back again, to open the university to ideas from the world of business, and to accelerate the development of ideas into marketable, scalable and profitable goods and services" (Vostal and Robertson 2012, pp.144-145). This has been described in direct opposition to a spirit of academic enquiry; "many academics view the rapid acceleration of an idea into a business product as alien, in part because of their own personal commitment to ideas as ideas and not business opportunities, and in part because the traditions of 'good' academic practice - disinterestedness, skepticism and rationality - sit uneasily with the demands of a business venture, such as passion, pace and risk" (ibid). Many of these demands may also sit uneasily with those at work in the cultural or creative economy, whose work may 
often be motivated as much by a belief in intrinsic value, rather than for economic gain. Here, understanding intermediary expertise as processual, rather than transactive, for us as intermediaries might be a more reflexive position to take (Virani and Pratt, 2016). However, this mode of analysis also involves being accountable to our own complicity in the production of creative economy-third mission assemblages, and how our actions as researchers, research managers, and practitioners are responsible for setting the conditions by which the promise and peril of the creative economy is made.

The fourth element of this analysis is how the creative economy-third mission is articulated by actors at work within its nexus, and the constitutive consequences of that articulation. Here I draw on the idea of calculative practice. This can take a wide variety of forms, from house numbering to make numerically categorise spaces (Rose-Redwood, 2008) to census gathering to produce detailed information about a given group of people (Hannah, 2000) through to the use of statistics to define industrial categories, such as has been observed in the creative economy. Measurements of these kinds are presented by those in power as incontrovertible representations of truth, where in actual fact they are political outcomes used to promote a way of governing as 'objective' and thus legitimate (Prince, 2013). Most importantly, calculative techniques are used to render the spaces and subjects that are to be governed visible to the other techniques of rule, such as through counting workers, qualifying claims about economic outputs through numerical accounts of success, or envisaging in the spaces being governed by measuring and dividing them into manageable units within which specific outputs can be measured.

The creative economy imaginary has been assembled through calculative practices that imagine, delineate, quantify the activities that constitute it. The same is increasingly true of universities (Shore and Wright, 2015), and in the university-creative economy nexus, there are countless examples of reports, working papers, and executive summaries, that mobilise number in a manner that emphasises the role of the university and its importance in regional and national growth; from Brighton Fuse (Sapsed and Nightingale, 2013), our own report of the REACT Hub (Dovey et al., 2016), to the Arts and Humanities Research Council's account of its Knowledge Exchange Hubs for the Creative Economy programme (AHRC, 2017), or the UUK (2010) and UA (Williams et al., 2018) documents already mentioned, the mobilisation of number as a form of participation in the policy conversation is notable. But it is also an act of compliance; the numbers used, the measurements being encouraged, fit into an established discourse about measuring the economy. As funding programmes continue to be beholden to funders that require evidence that fits this political rationale, are we only going to be able write reports that tell - either in part or in their entirety - the story our funders want to hear? 
Universities contribute to the development of any number of creative, practical, knowledge, and research activities. But in the framing of the creative economy the preconditions for those activities have been reshaped. This has produced a complicated arena for change in the university, affecting as it does the spaces where the institutions operate, the form work takes, the practice and identity of academic and professional service staff, and the practices of regulation and management in institutions. This has underpinned conceptual shifts in the raison d'etre of higher education itself, and the value of knowledge and its methods of production. In turn, creative economy policies have, inside the creative industries, and outside, experienced new opportunities to work with universities, to access new forms of expertise in the forms of academics, incubation schemes, graduate programmes, and so on. With co-production, co-creation and impact on the agenda, Larner (2012) notes, that it is in third mission activities that some researchers are finding possibilities to foreground practices of academic labour which eschew detached academic practice and instead engage in direct, collaborative work with those whose world we are exploring. Drawing on postcapitalist theory (Gibson-Graham, 2006), it is perhaps in work of the kind Larner describes that we might have a chance to 'imagine research otherwise' (Bill, 2016) by occupying positions that see inventiveness and creativity as other than economic, that hold power to account, and offer modes of being that provide an alternative to the logics of creative capitalism.

The challenge however, is one, often, of agency; and one in which the tension between the production of a space of research, education, and knowledge exchange is made by myriad competing processes and flows. As Gill (2014) shows, opportunities for change do not always equate with equitable working practices and processes. Yet, a collaborative mode of institutional and academic practice that might support those working under the auspices of the creative economy, might offer a way to develop alternatives. In this way economy discourses can be negotiated (McRobbie, 2011) and may give rise to different, spaces for action (Araya, 2010). Vostal and Robertson (2014 p. 145) describe changes to the temporality of the university as being "accompanied by a paradoxical set of counter-flows, undercurrents and backflows, which feed processes of deceleration." Being attentive to these might gave us a clue to where we can produce an alternative version of creativity, culture, or value.

\section{Conclusion}

This paper has sought to raise questions about the solidity and deterministic properties afforded to the creative economy-third mission. While beyond its scope to give a full case study of a given project as-assemblage, I hope that such an account will follow in a future 
paper. I wish to emphasise how these changes are not only being done to us as academics; we are also participating in them, as researchers, teachers and 'entrepreneurs'. We are constituent parts of its assemblage, and as Chris Gibson (2015 p. 477) points out, "much of our research and policy talk [about creative industries in regions] still unconsciously and uncritically reproduces its normative elements". So while I am hopeful concerted efforts in this space of contradiction can effect change, I am also concerned, as are many others, that the cost of that change - precarity, a lack of diversity, the aggressive emphasis on economic indicators and framings of creative production, and an over-reliance on the very notion of 'creative economies' - might prevent us from realising an alternative. But if we wish to create a university that is porous, ethical and values creativity not as 'fast innovation' but as a more embedded way of being, thinking, acting and knowing, that recognises its own power and privilege and seeks to address beneficial changes, and not simply spend our time reproducing a problematic creative economy, we must also hold ourselves to account.

\section{References}

AHRC, 2017. Creative Exchanges - The AHRC Knowledge Exchange Hubs for the Creative Economy. Arts and Humanities Research Council, Swindon.

Araya, D., 2010. Cultural Democracy: Universities in the Creative Economy. Policy Futures in Education 8, 217-231. https://doi.org/10.2304/pfie.2010.8.2.217

Bakhshi, H., Hargreaves, I., Mateos-Garcia, J., 2013. A Manifesto for the Creative Economy. Nesta, London.

Banks, M., 2009. Fit and working again? The instrumental leisure of the "creative class." Environment and Planning A 41, 668-681.

Banks, M., Hesmondhalgh, D., 2009. Looking for work in creative industries policy. international Journal of Cultural Policy 15, 415-430.

Belfiore, E., 2015. 'Impact', 'value' and 'bad economics': Making sense of the problem of value in the arts and humanities. Arts and Humanities in Higher Education 14, 95110. https://doi.org/10.1177/1474022214531503

Bell, D., 1973. The Coming of Post Industrial Society: A Venture in Social Forecasting. Penguin, Middlesex.

Bill, A., 2016. Counter-conduct in creative university research: deliberations on freedom. Higher Education Research \& Development 1-14. https://doi.org/10.1080/07294360.2016.1208158

Bill, A., 2008. Creative Girls: Fashion design education and governmentality. PhD Thesis: University of Aukland.

Bullen, E., Robb, S., Kenway, J., 2004. "Creative destruction”: knowledge economy policy and the future of the arts and humanities in the academy. Journal of Educational Policy 19, 3-22.

Christophers, B., 2007. Enframing creativity: power, geographical knowledges and the media economy. Transactions of the Institute of British Geographers 32, 235-247.

Comunian, R., Faggian, A., Jewell, S., 2011. Winning and losing in the creative industries: an analysis of creative graduates' career opportunities across creative disciplines. Cultural Trends 20, 291-308. https://doi.org/10.1080/09548963.2011.589710 
Comunian, R., Gilmore, A. (Eds.), 2016. Higher education and the creative economy: Beyond the campus. Routledge, London.

Crossick, G., 2006. Knowledge transfer without widgets: the challenge of the creative economy.

David, P.A., Foray, D., 2007. Economic Fundamentals of the Knowledge Society. Policy Futures in Education 1, 20-49.

DCMS, 2001. Creative Industries Mapping Document. Department for Culture Media and Sport, London.

DCMS, 1998. The Creative Industries Mapping Document. Department for Media, Culture and Sport, London.

Dovey, J., Moreton, S., Hargreaves, I., 2016. The REACT Report: 2012 -2016. REACT, Bristol.

Elden, S., 2007. Governmentality, calculation, territory. Environment and Planning D: Society and Space 25, 562-580.

Fougere, M., Solitander, N., 2010. Governmentality and the creative class: harnessing Bohemia, diversity and freedom for competitiveness. International Journal of Management Concepts and Philosophy 4, 41-59.

Garnham, N., 2005. From Cultural to Creative Industries: An analysis of the implications of the "creative industries" approach to arts and media policy making in the United Kingdom. international Journal of Cultural Policy 11, 15-29.

Gibson, C., 2015. Negotiating Regional Creative Economies: Academics as Expert Intermediaries Advocating Progressive Alternatives. Regional Studies 49, 476-479. https://doi.org/10.1080/00343404.2014.945249

Gibson-Graham, J.K., 2006. A postcapitalist politics. University of Minnesota Press, Minneapolis.

Gill, R., 2014. Academics, Cultural Workers and Critical Labour Studies. Journal of Cultural Economy 7, 12-30. https://doi.org/10.1080/17530350.2013.861763

Gill, R., Donaghue, N., 2016. Resilience, apps and reluctant individualism: Technologies of self in the neoliberal academy. Women's Studies International Forum 54, 91-99. https://doi.org/10.1016/j.wsif.2015.06.016

Gill, R., Pratt, A.C., 2008. In the social factory? Immaterial labour, precariousness and cultural work. Theory, Culture \& Society 25, 1-30. https://doi.org/10.1177/0263276408097794

Hannah, M.G., 2000. Governmentality and the mastery of territory in nineteenth-century America. Cambride University Press, Cambridge.

Hayek, F., 1945. The use of knowledge in society. The American Economic Review 35, 519530.

Hesmondhalgh, D., 2007. Creative Labour as a basis for a critique of creative industries policy, in: Lovink, G., Rossiter, N. (Eds.), MyCreativity Reader. Institute of Network Cultures, Amsterdam.

Hesmondhalgh, D., Nisbett, M., Oakley, K., Lee, D., 2015a. Were New Labour's cultural policies neo-liberal? International Journal of Cultural Policy 21, 97-114. https://doi.org/10.1080/10286632.2013.879126

Hesmondhalgh, D., Oakley, K., Lee, D., Nisbett, M., 2015b. What Was Creative Industries Policy? Film, Copyright and the Shift to Creative Economy, in: Culture, Economy and Politics, New Directions in Cultural Policy Research. Palgrave Macmillan, London, pp. 102-122. https://doi.org/10.1057/9781137426383_4

Hewison, R., 2011. "Creative Britain": myth or monument? Cultural Trends 20, 235-242. https://doi.org/10.1080/09548963.2011.589703 
Hughson, J., Inglis, D., 2001. "Creative Industries" and the arts in Britain: towards a "third way" in cultural policy? international Journal of Cultural Policy 7, 457-478.

Jessop, B., 2000. The State and the Contradictions of the Knowledge-Driven Economy. Dept of Sociology, Lancaster University http://www.comp.lancs.ac.uk/sociology.soc044rj.html.

Kenway, J., Bullen, E., Fahey, J., Robb, S., 2006. Haunting the Knowledge Economy. Routledge, Oxford.

Larner, W., 2012. Beyond commercialisation. Social Anthropology 20, 287-289. https://doi.org/10.1111/j.1469-8676.2012.00209.x

Larner, W., 2011. C-change? Geographies of crisis. Dialogues in Human Geography 1, 319 335. https://doi.org/10.1177/2043820611421552

Marteen, S., Mark, O., A., P., Michael, 2009. Re-Reading Education Policies - A Handbook Studying the Policy Agenda of the 21st Century - SensePublishers. Sense Publishers, Rotterdam, Netherlands.

McGuigan, J., 2010. Creative labour, cultural work and individualisation. International Journal of Cultural Policy 16, 323-335. https://doi.org/10.1080/10286630903029658

McRobbie, A., 2011. Variant issue 41 | Re-Thinking Creative Economy as Radical Social Enterprise [WWW Document]. URL http://www.variant.org.uk/41texts/amcrobbie41.html (accessed 6.7.18).

McRobbie, A., 2002. Clubs to companies: notes on the decline of political culture in speeded up creative worlds. Cultural Studies 16, 516-531.

Miller, T., 2009. From creative to cultural industries: not all industries are cultural and no industries are creative. Cultural Studies 23, 88-99.

Mommaas, H., 2004. Cultural Clusters and the Post-industrial City: Towards the Remapping of Urban Cultural Policy. Urban Studies 41, 507-532.

Moreton, S., 2016. Rethinking 'knowledge exchange': New approaches to collaborative work in the arts and humanities. International Journal of Cultural Policy 22, 100-115.

Mould, O., Vorley, T., Roodhouse, S., 2009. Realizing capabilities - academic creativity and the creative industries. Creative Industries Journal - Creativ Indust J 1, 137-150. https://doi.org/10.1386/cij.1.2.137_1

Oakley, K., 2006. Include Us Out-Economic Development and Social Policy in the Creative Industries. Cultural Trends 15, 255-273. https://doi.org/10.1080/09548960600922335

Oakley, K., 2004. Not So Cool Britannia: The Role of the Creative Industries in Economic Development. International Journal of Cultural Studies 7, 67-77.

OECD, 1996. The Knowledge-Based Economy. OECD: online http://www.oecd.org/dataoecd/51/8/1913021.pdf(21.05.07), Paris.

Osborne, T., 2004. On mediators: intellectuals and the ideas trade in the knowledge society. Economy and Society 35, 279-306.

Osborne, T., 2003. Against "creativity": a philistine rant. Economy and Society 32, 507-525.

Peck, J., 2005. Struggling with the Creative Class. International Journal of Urban and Regional Research 29, 740-770.

Pereira, M. do M., 2016. Struggling within and beyond the Performative University: Articulating activism and work in an "academia without walls." Women's Studies International Forum 54, 100-110. https://doi.org/10.1016/j.wsif.2015.06.008

Pratt, A.C., 2005. Cultural Industries and Public Policy: an Oxymoron? international Journal of Cultural Policy 11, 31-44.

Prince, R., 2017. Local or global policy? Thinking about policy mobility with assemblage and topology. Area 49, 335-341. https://doi.org/10.1111/area.12319 
Prince, R., 2014. Consultants and the global assemblage of culture and creativity. Transactions of the Institute of British Geographers 39, 90-101. https://doi.org/10.1111/tran.12012

Prince, R., 2013. Calculative Cultural Expertise? Consultants and Politics in the UK Cultural Sector: Sociology. https://doi.org/10.1177/0038038513502132

Prince, R., 2012. Metaphors of policy mobility: fluid spaces of "creativity" policy. Geografiska Annaler: Series B, Human Geography 94, 317-331. https://doi.org/10.1111/geob.12001

Rose, N., 1999. Powers of Freedom: Reframing Political Thought. Cambridge University Press, Cambridge.

Rose-Redwood, R.S., 2008. Indexing the great ledger of the community: urban house numbering, city directories, and the production of spatial legibility. Journal of Historical Geography 34, 286-310.

Ross, A., 2008. The New Geography of Work: Power to the Precarious? Theory, Culture and Society $25,31-49$.

Ross, A., 2007. Nice Work if You Can Get It: The Mercurial Career of Creative Industries Policy, in: Lovink, G., Rossiter, N. (Eds.), MyCreatvity Reader. Institute of Network Cultures, Amsterdam.

Sapsed, J., Nightingale, P., 2013. The Brighton fuse report. Brighton Fuse, Brighton.

Shore, C., McLauchlan, L., 2012. 'Third mission' activities, commercialisation and academic entrepreneurs. Social Anthropology 20, 267-286. https://doi.org/10.1111/j.14698676.2012.00207.x

Shore, C., Wright, S., 2015. Governing by numbers: audit culture, rankings and the new world order. Social Anthropology 23, 22-28. https://doi.org/10.1111/14698676.12098

Thrift, N., 2000. Performing Cultures in the New Economy. Annals of the Association of American Geographers 90, 674-692. https://doi.org/10.1111/0004-5608.00217

UUK, 2010. Creating Prosperity: the role of higher education in driving the UK's creative economy 84.

Virani, T., Pratt, A.C., 2016. Intermediaries and the knowledge exchange process: The case of the creative industries and higher education, in: Comunian, R., Gilmore, A. (Eds.), Higher Education and the Creative Economy: Beyond the Campus. Routledge, London.

Vostal, F., Robertson, S., 2012. Knowledge Mediators and Lubricating Channels: On the Temporal Politics of Remissioning the University. TOPIA: Canadian Journal of Cultural Studies 1.

Watermeyer, R., Chubb, J., 2018. Evaluating 'impact' in the UK's Research Excellence Framework (REF): liminality, looseness and new modalities of scholarly distinction. Studies in Higher Education 1-13. https://doi.org/10.1080/03075079.2018.1455082

Williams, A., Dovey, J., Cronin, Bruce, Garside, Peter, Flintham, Matthew, Smith, Matthew, Barrett, David, Brooks, Richard, Boddington, Anne, Taylor, Faye, 2018. Hidden Story: Understanding Knowledge Exchange Partnerships with the Creative Economy.

Wright, S., Shore, C., 2017. Death of the Public University?: Uncertain Futures for Higher Education in the Knowledge Economy. Berghahn Books. 